Formatif: Jurnal Ilmiah Pendidikan MIPA

Vol. 9, No. 4, December 2019, pp. 333-338

p-ISSN: 2088-351X

e-ISSN: 2502-5457

DOI: http://dx.doi.org/10.30998/formatif.v9i4.4132

\title{
The Effect of Jigsaw Cooperative Learning Methods on Mathematical Communication Ability Viewed Based on Student Personality
}

\author{
Pengaruh Metode Pembelajaran Kooperatif Jigsaw Terhadap Kemampuan \\ Komunikasi Matematis Ditinjau Berdasarkan Kepribadian Siswa
}

\author{
Islah Ziauddin Sardar Yeubun (*) \\ Universitas Negeri Jakarta \\ Anton Noornia \\ Universitas Negeri Jakarta \\ Lukita Ambarwati \\ Universitas Negeri Jakarta
}

Received: July 16, 2019

Revised: December 02, 2019

Accepted: December 02, 2019

\begin{abstract}
This study uses a quasi-experimental method with the final design control test of mathematical communication skills in terms of student personality through personality tests. The sample of this study was students of class XI-IPS in MAN 6 Kampung Dukuh and MAN 6 Cibubur East Jakarta in the odd semester 2018/2019 Academic Year as many as 88 people. The instrument used in this study is a description question and personality questionnaire. The results showed that 1) The ability of mathematical communication students who got the cooperative jigsaw method was higher than the students who received conventional learning, 2) There were interactions between learning methods and personalities on mathematical communication skills, 3) Mathematical communication skills of students with extroverted personalities given jigsaw cooperative method treatment is higher than those given conventional learning treatment, 4) Mathematical communication skills of students with introverted personalities treated with cooperative jigsaw methods are lower than those given conventional learning treatments. Thus, jigsaw cooperative learning is better applied to students with an extracurricular personality.
\end{abstract}

Keywords: Mathematical Communication, Jigsaw, Personality

(*) Corresponding Author: $\quad$ zhieaedin@gmail.com - 085782311544

How to Cite: Yeubun, I. Z. S., Noornia, A., \& Ambarwati, L. (2019). The effect of jigsaw cooperative learning methods on mathematical communication ability viewed based on student personality. Formatif: Jurnal Ilmiah Pendidikan MIPA, 9 (4): 333-338. http://dx.doi.org/10.30998/formatif.v9i4.4132

\section{PENDAHULUAN}

Tema pengembangan kurikulum 2013 tentang standar kompetensi lulusan (SKL) yang dimuat dalam Permendikbud No. 54 tahun 2013 kualifikasi lulusan memuat salah satunya poin keterampilan. Keterampilan yang dimaksud dalam pembelajaran matematika ialah kemampuan komunikasi (Kemendikbud, 2016). Komunikasi dalam matematika 
diistilahkan dengan kemampuan matematis, yaitu kemampuan siswa untuk menghubungkan benda nyata, gambar, dan diagram ke dalam idea matematika; menjelaskan idea, situasi dan relasi matematik secara lisan atau tulisan dengan benda nyata, gambar, grafik, dan aljabar; menyatakan peristiwa sehari-hari dalam bahasa atau simbol matematika; mendengarkan, berdiskusi, dan menulis tentang matematika; membaca dengan pemahaman suatu presentasi matematika tertulis, membuat konjektur, menyusun argumen, merumuskan definisi dan generalisasi; menjelaskan dan membuat pertanyaan tentang matematika yang telah dipelajari (Sumarmo, 2005). ada dua jenis kemampuan komunikasi, yaitu tulisan dan lisan. Ernest (1998) menjelaskan bahwa. (a) Komunikasi matematik tulisan menekankan pada interaksi siswa dalam dunia yang kecil dan penafsiran non-verbal serentak mereka terhadap interaksi lainnya dan (b) Komunikasi matematik lisan menekankan interaksi lisan mereka satu sama lain dan dengan guru ketika mereka membangun tujuan dengan membuat pembagian yang sesuai. Menurut Santos \& Semana (2015) observasi yang difokuskan pada kemampuan komunikasi matematis siswa adalah hal yang paling efektif untuk mengetahui tingkat kemampuan kognitif siswa terhadap apa yang mereka pelajari dan akan dipelajari sedangkan komunikasi matematis tulisan adalah kemampuan atau keterampilan siswa dalam menggunakan kosa kata, notasi, dan struktur matematis baik dalam bentuk penalaran, koneksi, maupun problem solving. Berdasarkan analisis terhadap konsep dan model, semua merupakan representasi dari kemampuan komunikasi siswa yang harus dimaksimalkan dengan dukungan dalam wadah pembelajaran yang sesuai.

Selain itu interaksi antar siswa jadi poin penting siswa mampu mengeksplorasi kemampuan komunikasinya, karena dengan siswa berintraksi siswa akan saling bertukar informasi dan konsep mengenai pembelajaran matematika, maka pembelajaran yang memiliki dasar kerjasama dan keterlibatan semua siswa dalam kelompok-kelompok kecil dan besar menjadi kesatuan yang baik adalah pembelajaran yang tepat untuk diterapkan. Menurut Roger (1992), pembelajaran kooperatif jigsaw adalah pembelajaran kelompok yang terorganisir dan mampu memberi kesempatan siswa untuk saling bertukar informasi dan gagasan yang mereka miliki (dalam bentuk lisan maupun tertulis (Roger, 1992). Dalam model jigsaw II versi Aronson (Huda, 2012), kelas dibagi menjadi suatu kelompok kecil yang heterogen diberi nama tim jigsaw II dan materi dibagi sebanyak kelompok menurut anggota timnya. Tiap-tiap tim diberikan satu set materi yang lengkap dan masing-masing individu ditugaskan untuk memilih topik mereka. Kemudian siswa dpiisahkan menjadi tim atau kelompok "ahli" dan "asal" yang terdiri dari seluruh siswa di kelas yang mempunyai bagian informasi yang sama.

Kepribadian siswa jadi bagian yang tak kalah penting dalam memberi dampak yang dinamis pada pembelajaran. Hal ini menjadi perhatian yang tak kalah pentingnya untuk ditinjau sebagai hal yang mungkin mendukung atau bahkan menghambat siswa berkembang. Teori kepribadian Jung membagi dimensi kepribadian menjadi empat pasang bagian, salah satunya adalah tipe kepribadian intovert dan ekstrover (Eysenck, 2002). Menurut Pervin (2015) siswa dengan tipe kepribadian introver memiliki sifat tenang, suka merawat diri, bersikap hati-hati, pemikir, kurang percaya pada keputusan yang impulsif, lebih suka hidup teratur, suka murung, kuatir, kaku, sederhana, pesimis, suka menyendiri, kurang suka bergaul, pendiam, pasif, berhati-hati, tenggang hati, damai, terkendali, dapat diandalkan, menguasai diri. Namun permasalahan yang timbul dari pembelajaran matematika yang peneliti amati pada populasi yang terkait bahwa. 1) Perhatian yang sedikit terhadap kemampuan komunikasi matematis, 2) Pemilihan metode kurang tepat guna mengeksplorasi kemampuan matematis siswa secara lisan maupun tulisan, 3) Pemilihan treatment yang terbatas agar siswa secara sistematis mengungkap gagasan secara tertulis dan kemudian mengkomunikasikannya secara lisan, 4) Perhatian 
terhadap karakteristis kepribadian siswa dalam metode dan treatment yang diberikan sering diabaikan, sehingga perlu adanya penelitian yang melihat pengaruh penggunaan metode jigsaw terhadap kemampuan komunikasi matematis yang ditinjau berdasarkan kepribadian siswa, dengan memerhatikan adanya 1) Perbedaan kemampuan antar metode, 2) Interaksi antara metode, kepribadian dan kemampuan, 3) Perbedaan kemampuan siswa ekstrover, dan 4) Perbedaan kemampuan siswa introver.

\section{METODE}

Penelitian ini merupakan penelitian kuantitatif, dengan metode eksperimen sети, dimana tidak secara acak memasukkan para partisipan ke dalam dua kelompok tertentu (nonrandom assignment). Rancangan perlakuan pada penelitian ini adalah desain by level $2 \times 2$, yang terdiri dari model pembelajaran (A), yaitu kelompok kelas eksperimen dengan pembelajaran Jigsaw II $\left(\mathrm{A}_{1}\right)$ dan kelas kontrol dengan pembelajaran konvensional $\left(\mathrm{A}_{2}\right)$, sedangkan kepribadian siswa (B) juga terdiri dari dua kelompok yaitu kelompok siswa bertipe kepribadian introver $\left(\mathrm{B}_{1}\right)$ dan kelompok siswa bertipe kepribadian ekstrover $\left(\mathrm{B}_{2}\right)$, dengan tiga variable penelitian, yaitu variabel terikat, variebel bebas dan variable moderat.

Penentuan sampel dilakukan secara multistage sampling terhadap Madrasah Aliyah Negeri (MAN) di wilayah Jakarta Timur yang terakreditasi A, lalu dilanjutkan dengan random sampling terhadap sekolah-sekolah tersebut untuk mengetahui populasi target dan terjangkau. Populasi target terdiri dari seluruh peserta didik MAN di wilayah Jakarta Timur. Kemudian populasi terjangkau terdiri dari seluruh siswa kelas XI MAN 6 Kampung Duku dan seluruh siswa kelas XI MAN 6 Cibubur. Data dalam penelitian diperoleh melalui hasil tes pra syarat, tes kemampuan, serta tes kepribadian. Hasil dari tes pra syarat digunakan untuk menganalisis normalitas melalui uji Kolmogorov-Smirnov melalui media SPSS-23 dengan taraf signifikan $\alpha=0,05$ dimana kriteria pengujian $\mathrm{H}_{0}$ : data berdistribusi normal $\mathrm{H}_{1}$ : data tidak berdistribusi normal, kemudian menganalisis homogenitas melalui uji Levene's, memperhatikan $\mathrm{H}_{0}$ diterima jika Signifikansi $>\alpha=$ 0,05 dan $\mathrm{H}_{0}$ ditolak Signifikasni $<\alpha=0,05$ selanjutnya menganalisis kesamaan rata-rata dengan one way anova dan menentukan taraf signifikansi $>\alpha=0,05$ maka $\mathrm{H}_{0}$ diterima untuk sampel yang kita ambil, kemudian kita bagi sampel berdasarkan tinjauan kepribadian (introver-ekstrover) dengan tes MBTI, setelah terkelompok berdasarkan kepribadian lalu diberi perlakuan, kelas eksperimen dengan metode kooperatif jigsaw dan kelas kontrol dengan metode konvensional selanjutnya di akhir dengan tes kemampuan komunikasi matematis yang tesnya telah melalui uji validitas dan reabilitas untuk mengetahui adanya perbedaan antar metode (dengan uji anava dua jalur), interaksi, serta perbedaan kemampuan masing-masing kepribadian pada masing-masing metode (dengan uji-t).

\section{HASIL DAN PEMBAHASAN}

Langkah pertama adalah menganalisis normalitas, homogenitas, dan kesamaan rata-rata populasi yang terpilih secara acak. Berdasarkan perhitungan dari nilai tes pra syarat siswa kelas XI IPS MAN 6 Kampung Dukuh dan siswa kelas XI IPS MAN 6 Cibubur dengan menggunakaan SPSS-23, bahwa hanya 1 kelas yang dinyatakan gugur dengan 7 kelas lainnya diterima, selanjutnya uji homogenitas menggunakan SPSS menunjukan nilai Levene's statistik dari 7 kelas mempunyai variansi yang sama atau 
Formatif: Jurnal Ilmiah Pendidikan MIPA

Vol. 9, No. 4, December 2019, pp. 333-338

p-ISSN: 2088-351X

e-ISSN: 2502-5457

DOI: http://dx.doi.org/10.30998/formatif.v9i4.4132

homogen, kemudian diakhiri dengan uji anava satu jalur untuk menentukan kesamaan rata-rata kelas yang hasilnya juga menunjukan kesamaan rata-rata, dengan demikian sampel yang dimaksud siap diberi perlakuan, dalam perlakuan siswa dikelompokan menjadi dua kepribadian (introver-ekstrover).

Perlakuan dilakukan pada materi matriks dengan kelas eksperimen menggunakan metode kooperatif jigsaw dengan bantuan jurnal aktivitas pembelajaran matematika (japma) saat siswa berada di kelompok ahli maupun saat persentasi di kelompok asal. Di akhir pertemuan, siswa kelas eksperimen dan kontrol diuji dengan tes kemampuan komunikasi matematis, hasilnya menunjukan bahwa terdapat perbedaan yang signifikan pada kemampuan komunikasi matematis siswa yang mendapat perlakuan metode kooperatif jigsaw dengan siswa yang mendapat perlakuan dengan metode pembelajaran konvensional. Hal ini, berdasarkan data hasil perhitungan uji anava pada kedua kelompok pembelajaran dengan Sig. $=0.04<0.05$ pada taraf signifikan 0.05 maka $\mathrm{H}_{0}$ ditolak.

Tabel 1. Nilai Uji Anava Dua Jalur Pengaruh Metode Pembelajaran dan Kepribadian siswa serta Interaksinya terhadap Kemampuan Komunikasi Matematis

\begin{tabular}{clllll}
\hline Source & $\begin{array}{c}\text { Type III Sum } \\
\text { of Squares }\end{array}$ & Df & $\begin{array}{c}\text { Mean } \\
\text { Square }\end{array}$ & F & Sig. \\
\hline Corrected Model & $10516.324^{\mathrm{a}}$ & 3 & 3505.441 & 12.308 & .000 \\
Intercept & 263386.702 & 1 & 263386.702 & 924.780 & .000 \\
Pemb. & 1235.178 & 1 & 1235.178 & 4.337 & .040 \\
Keprbdn & 275.178 & 1 & 275.178 & .966 & .328 \\
Pemb.* & 9031.146 & 1 & 9031.146 & 31.709 & .000 \\
Keprbdn & & & & & \\
\hline
\end{tabular}

Menjelaskan pula bahwa kemampuan komunikasi matematis siswa yang mendapat perlakuan metode kooperatif Jigsaw lebih tinggi daripada kemampuan komunikasi matematis siswa yang mendapat konvensional.

Hal lain, ditunjukan pada interaksi anatara metode, kepribadian dan kemampuan komunikasi matematis, bahwa terdapat interaksi antara netode dengan kepribadian dengan Sig. $=0.00<0.05$ pada taraf signifikan 5\% dengan ini $\mathrm{H}_{0}$ ditolak. Berarti bahwa interaksi yang sangat signifikan antara metode pembelajaran dan kepribadian terhadap kemampuan komunikasi. Metode pembelajaran dan kepribadian secara bersamaan memerngaruhi kemampuan komunikasi matematis.

Hasil uji-t perbedaan kemampuan komunikasi matematis siswa antar kepribadian ekstrover dengan taraf sig. $\alpha=0,05$ dan kriteria tolak $\mathrm{H}_{0}$ adalah $\mathrm{t}_{\text {hitung }}>\mathrm{t}_{\text {tabel }}$ didapat hasil bahwa $t_{\text {hitung }}=6,291>t_{\text {tabel }}=2,016$ dengan demikian maka $\mathrm{H}_{0}$ ditolak. 
Formatif: Jurnal Ilmiah Pendidikan MIPA

Vol. 9, No. 4, December 2019, pp. 333-338

p-ISSN: 2088-351X

e-ISSN: 2502-5457

DOI: http://dx.doi.org/10.30998/formatif.v9i4.4132

Tabel 2. Nilai Uji-t Perbedaan Kemampuan Komunikasi Matematis pada Siswa yang Memiliki Kepribadian Ekstrover

\begin{tabular}{cccccc}
\hline & & $\begin{array}{c}\text { Levene's Test for } \\
\text { Equality of } \\
\text { Variances }\end{array}$ & \multicolumn{2}{c}{$\begin{array}{c}\text { t-test for Equality of } \\
\text { Means }\end{array}$} \\
\cline { 3 - 6 } & $\mathrm{F}$ & $\mathrm{Sig}$. & $\mathrm{T}$ & $\mathrm{Df}$ \\
$\begin{array}{c}\text { Equal variances } \\
\text { Kem.Ksumed } \\
\text { Matematis }\end{array}$ & .383 & .539 & 6.291 & 43 \\
\hline $\begin{array}{c}\text { Equal variances } \\
\text { not assumed }\end{array}$ & & & 6.267 & 41.184 \\
\hline
\end{tabular}

Didapatkan bahwa terdapat perbedaan kemampuan komunikasi matematis pada siswa ekstrover dengan metode jigsaw dan metode konvensional. Dimana siswa ekstrover dengan metode jigsaw memiliki nilai lebih baik dari konvensional. Sedangkan pada siswa introver, hasil uji-t perbedaan kemampuan komunikasi matematis siswa dengan taraf signifikansi $\alpha=0,05$ dan kriteria tolak $\mathrm{H}_{0}$ adalah $\mathrm{t}_{\text {hitung }}<\mathrm{t}_{\text {tabel }}$ didapat hasil bahwa $\mathrm{t}_{\text {hitung }}=$ $-2,246<-\mathrm{t}_{\text {tabel }}=2,016$ dengan demikin maka $\mathrm{H}_{0}$ ditolak.

Tabel 3. Nilai Uji-t Perbedaan Kemampuan Komuniaksi Matematis pada Siswa dengan Kepribadian Introver

\begin{tabular}{cccccc}
\hline & & \multicolumn{2}{c}{$\begin{array}{c}\text { Levene's Test for } \\
\text { Equality of } \\
\text { Variances }\end{array}$} & \multicolumn{2}{c}{$\begin{array}{c}\text { t-test for Equality } \\
\text { of Means }\end{array}$} \\
\cline { 3 - 6 } & F & Sig. & $\mathrm{T}$ & $\mathrm{Df}$ \\
Kem.Komunikasi & $\begin{array}{c}\text { Equal variances } \\
\text { assumed }\end{array}$ & .215 & .645 & - & 43 \\
Matematis & $\begin{array}{c}\text { Equal variances not } \\
\text { assumed }\end{array}$ & & & -2.246 & \\
\hline
\end{tabular}

Hal ini, berarti bahwa terdapat perbedaan kemampuan komunikasi matematis pada siswa yang mendapat perlakuan metode kooperatif jigsaw dengan siswa yang mendapat perlakuan metode konvensional pada siswa yang memiliki kepribadian introver dengan siswa intover yang mendapat metode konvensional lebih tinggi daripada metode kooperatif jigsaw. Kemampuan siswa berkepribadian introver pada kelas eksperimen lebih rendah dibanding dengan kelas kontrol, yang memperlihatkan kurang tepatnya pembelajaran kooperatif jigsaw pada siswa introver. Hal berbalik diperlihatkan pada siswa ekstrover, siswa ektrover dikelas eksperimen menunjukan hasil kemampuan komunikasi matematis yang lebih dibandingkan dengan kelas kontrol, yang berarti menunjukan bahwa metode kooperatif jigsaw baik digunakan pada siswa berkepribadian ekstrover. Hal ini sejalan dengan hasil penelitian yang dilakukan oleh Nur Maziyah (Ulya, 2017) bahwa interaksi terjadi pada pemilihan metode pada setiap variabelnya dengan tipe kepribadian terhadap kemampuan yang ingin diamati, juga pada penelitian Yubhanir dan An Nuril (Yubhanir M. R. \& An Nuril M. F, 2017) bahwa terdapat pengaruh pada tipe kepribadian siswa dalam beradaptasi dengan model atau metode yang diterapkan padanya, menurutnya siswa ektrover mampu beradaptasi dengan baik pada metode baru, aktif berinteraksi dan kerja sama, tetapi siswa introver memiliki kemampuan menarik simpulan lebih baik dari siswa ekstrover. 
Formatif: Jurnal Ilmiah Pendidikan MIPA

Vol. 9, No. 4, December 2019, pp. 333-338

p-ISSN: 2088-351X

e-ISSN: 2502-5457

DOI: http://dx.doi.org/10.30998/formatif.v9i4.4132

\section{PENUTUP}

Berdasarkan hasil penelitian dan pembahasan tersebut diperoleh beberapa hal diantaranya: 1) Peningkatan kemampuan komunikasi matematis siswa yang mendapat metode kooperatif jigsaw lebih tinggi daripada siswa yang mendapat pembelajaran konvensional. Maka metode kooperatif jigsaw perlu diterapkan dalam proses pembelajaran, 2) terdapat interaksi antara metode pembelajaran dan kepribadian terhadap kemampuan komunikasi matematis. Hal ini menunjukkan bahwa kemampuan komunikasi matematis siswa dipengaruhi oleh metode pembelajaran dan tipe kepribadian, 3) kemampuan komunikasi matematis siswa dengan kepribadian ekstrover yang diberi perlakuan metode kooperatif jigsaw lebih tinggi daripada yang diberi perlakuan pembelajaran konvensional, dan 4) kemampuan komunikasi matematis siswa dengan kepribadian introver yang diberi perlakuan metode kooperatif jigsaw lebih rendah daripada yang diberi perlakuan pembelajaran konvensional.

\section{DAFTAR PUSTAKA}

Ernest, P. (1998). Social constructivism as a philosophy of mathematics. Suny Press.

Eysenck, H. J. (2002). Personality and social psychology. Behaviour Research and Therapy. https://doi.org/10.1016/0005-7967(65)90022-7

Huda, M. (2012). Cooperative Learning Metode, Teknik, Struktur dan Penerapan. (S. Zuhri Qudsy, Ed.) (V). Yogyakarta: Pustaka Pelajar.

Kemendikbud. (2016). Permendikbud No 20 Tahun 2016 Tentang SKL Pendidikan Dasar dan Menengah. Menteri Pendidikan Dan Kebudayaan. https://doi.org/10.1017/CBO9781107415324.004

Pervin, L. A. (2015). Goal concepts in personality and social psychology. Goal Concepts in Personality and Social Psychology. https://doi.org/10.4324/9781315717517

Santos, L., \& Semana, S. (2015). Developing mathematics written communication through expository writing supported by assessment strategies. Educational Studies in Mathematics, 88(1), 65-87. https://doi.org/10.1007/s10649-014-9557-z

Ulya, N. M. (2016). Pengaruh metode pembelajaran dan tipe kepribadian terhadap hasil belajar bahasa Arab (studi eksperimen pada MAN 1 Semarang). Jurnal Pendidikan Islam, 10 (1).

Yubhanir M. R. \& An Nuril M. F. (2017). Kemampuan penalaran siswa SMP dalam menyelesaikan masalah ditinjau dari kepribadian introver dan ekstrover pada materi kalor. Jurnal Mahasiswa Unesha, 5, 138-146. 